Section Editor

Mitchell S.V. Elkind,

MD, MS

Partha S. Ghosh, MD

Shalaka Indulkar, MD

Manikum Moodley,

$\mathrm{MBChB}$

Address correspondence and reprint requests to Dr. Partha $S$. Ghosh, Desk S60, Pediatric

Neurology Center, Cleveland Clinic, 9500 Euclid Avenue,

Cleveland, OH 44195

ghoshp3@ccf.org

\title{
Teaching Video NeuroImages: Shake Mom's hand to get the diagnosis
} 的

Figure Inverted V-shaped (tented/fish-shaped) upper lip characteristic of facial weakness in congenital myotonic dystrophy

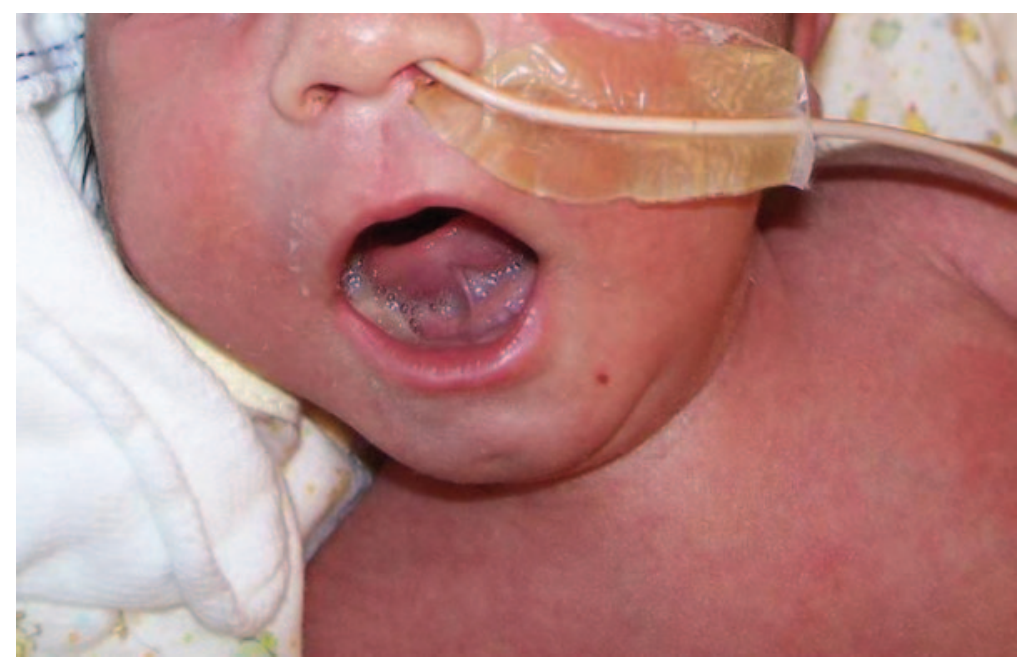

A term male newborn was admitted to the neonatal intensive care unit for respiratory distress and feeding difficulty. His 19-year-old mother was apparently healthy. The baby had generalized hypotonia, weakness, a weak cry, and a tented upper lip (figure). Maternal examination facilitated diagnosis (videos 1 and 2 on the Neurology ${ }^{\circledR}$ Web site at www.neurology.org). Genetic testing identified $>99$ CTG repeats, confirming myotonic dystrophy type 1 (DM1), a trinucleotide repeat disorder involving the $D M P K$ gene. ${ }^{1}$ Congenital DM1, usually maternally transmitted, ${ }^{2}$ presents antenatally with polyhydramnios and reduced fetal movements. Postnatally it presents with generalized weakness, hypotonia, respiratory compromise, and feeding difficulties. ${ }^{1}$ The inverted V-shaped upper lip represents facial weakness. Because myotonia is absent in newborns, examination of the mother is diagnostic.

\section{AUTHOR CONTRIBUTIONS}

Dr. Ghosh collected and organized the data and wrote the first manuscript (including the first draft). Dr. Moodley conceptualized the study, verified the results, and revised the manuscript at all stages. Dr. Indulkar verified the results and revised the manuscript at all stages.

\section{REFERENCES}

1. Turner C, Hilton-Jones D. The myotonic dystrophies: diagnosis and management. J Neurol Neurosurg Psychiatry 2010;81:358-367.

2. Zeesman S, Carson N, Whelan DT. Paternal transmission of the congenital form of myotonic dystrophy type 1: a new case and review of the literature. Am J Med Genet 2002;22:107:222-226.
Supplemental data at www.neurology.org 


\title{
Neurology
}

\author{
Teaching Video NeuroImages: Shake Mom's hand to get the diagnosis \\ Partha S. Ghosh, Shalaka Indulkar and Manikum Moodley \\ Neurology 2011;77; e114 \\ DOI 10.1212/WNL.0b013e318236ef77
}

\section{This information is current as of November 7, 2011}

\section{Updated Information \&}

Services

Supplementary Material

References

Subspecialty Collections

Permissions \& Licensing

Reprints including high resolution figures, can be found at: http://n.neurology.org/content/77/19/e114.full

Supplementary material can be found at: http://n.neurology.org/content/suppl/2011/11/06/77.19.e114.DC1

This article cites 1 articles, 1 of which you can access for free at: http://n.neurology.org/content/77/19/e114.full\#ref-list-1

This article, along with others on similar topics, appears in the following collection(s):

All Clinical Neurology

http://n.neurology.org/cgi/collection/all_clinical_neurology

All Neuromuscular Disease

http://n.neurology.org/cgi/collection/all_neuromuscular_disease

Neonatal

http://n.neurology.org/cgi/collection/neonatal

Trinucleotide repeat diseases

http://n.neurology.org/cgi/collection/trinucleotide_repeat_diseases

Information about reproducing this article in parts (figures,tables) or in its entirety can be found online at:

http://www.neurology.org/about/about_the_journal\#permissions

Information about ordering reprints can be found online:

http://n.neurology.org/subscribers/advertise

Neurology ${ }^{\circledR}$ is the official journal of the American Academy of Neurology. Published continuously since 1951, it is now a weekly with 48 issues per year. Copyright Copyright $@ 2011$ by AAN Enterprises, Inc.. All rights reserved. Print ISSN: 0028-3878. Online ISSN: 1526-632X.

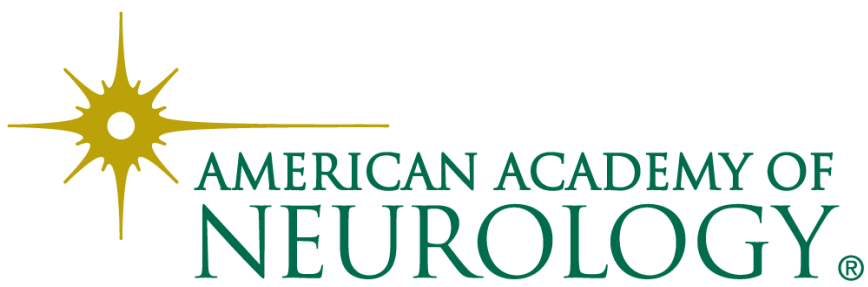

